Document downloaded from:

http://hdl.handle.net/10251/95023

This paper must be cited as:

Lorenzo Hernández, MC. (2016). Animated Jams: the Secret Joy of Collective Films. Animation Practice Process \& Production. 5:101-115. doi:10.1386/ap3.5.1.101_1

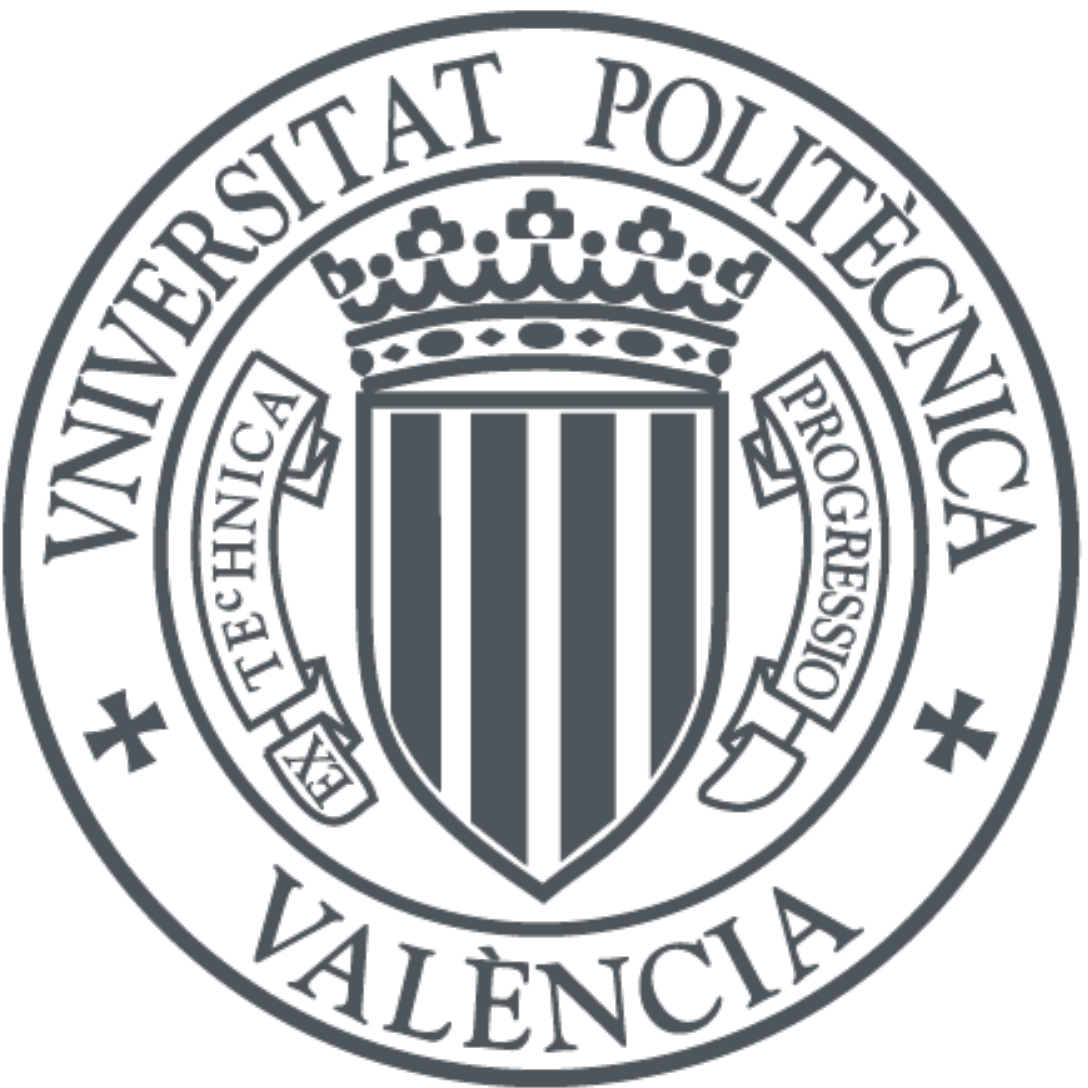

The final publication is available at

https://doi.org/10.1386/ap3.5.1.101_1

Copyright Intellect

Additional Information 


\section{Animated 'Jams': The Secret Joy of Collective Films}

\section{Introduction}

If a 'jam session' is an informal meeting where musicians improvise, we would regard as animated 'jams' those collective films where a number of independent animators are invited to contribute with a scene, freely adapted to a guideline or basic requirement - as when jazz musicians periodically return to the same musical theme during the 'jam session'. Such a common premise, which can be a format, a visual pattern, or a generic theme, serve to animators to make the continuity between different scenes easier, resulting heterogeneous yet coherent films.

Also, animated 'jams' are widely used as training practice at animation schools, since these collective films serve to join efforts easily and quickly. With this purpose, teachers issue a proposal, and work as coordinators of a team without hierarchies, where all participants are responsible of their own scenes. This simple methodology is an alternative to planned teamwork with division of labour, instead allowing all participants to animate simultaneously their respective scenes. Furthermore, since an idea or format prevails over narrative, in animated 'jams' it is easier to conceive situations and visual solutions that normally would have no place in a more orthodox film.

Firstly, this essay will provide an overview of animated 'jams', paying attention to some significant films coordinated and animated by independent animators. Secondly, we will delve into animated 'jams' as learning experiences, when they are produced at workshops and educational environments, eventually pointing to an outstanding figure: Miquel Guillem, animation lecturer at Universitat Politècnica de València, who began proposing these practices in the classroom to state the need for working together. Thirdly, we will use as a case study the short film The Cat Dances with its Shadow (El gato baila con su sombra, María Lorenzo [ed.], 2012), produced by the Researching Group of Animation: Art and Industry (UPV), bringing together the efforts of students and professors from two Master degrees - Valencia and Palermo; being a relevant film at festivals, it also served as posthumous tribute to Miquel Guillem ${ }^{1}$.

\section{Part 1_Animated 'jams': an overview}

As we advanced in the introduction, animated 'jams' are open proposals that avoid the constraints of a complex planning and storytelling. Instead, animated 'jams' are devised to stimulate individual imagination within a horizontal working environment, where all participants are equally prominent. Moreover, it is commonplace to find various creative techniques closer to experimental animation than to more conventional productions.

Additionally, producing animated 'jams' is inexpensive. They often do not require the installation of a studio, since participants work from their respective hometowns, limiting spending to postproduction. Other times, the initiative comes from institutions that find 
funding to cover costs of materials and equipment, although very often these animators contribute freely. In these cases, compensation comes from being part of a unique team that gathers strong personalities, resulting in a kind of film generally well accepted in festivals.

It is important to stress here that not every collective animation film is, by itself, a 'jam'. In animated 'jams', as noted earlier, improvisation is a significant component, together with the notion of authorship. Despite being a visibly heterogeneous film, with a variety of graphic styles according to the director of each scene, the short film T.R.A.N.S.I.T. (Piet Kroon, 1998) does not obey the spirit of the 'jams', since it adheres to strict planning to tell a mystery story - backwards.

By contrast, the bold proposal by Marv Newland, Anijam (1984), would be the paradigmatic example of this particular film genre. Newland reunited the efforts of 22 artist animators worldwide, who were provided with the very first and last frame of their respective scenes - the image of an eccentric character designed by Newland, immersed in various situations. Naturally, animators should not know what would come before or after their own scenes, being only the editor who would give continuity to the whole. Thus, Newland coordinated the project ensuring the continuity between the scenes, all the same length, accompanying the flow of images with a soundtrack that combined sounds and silence, periodically returning to the same music theme - a tango. Significantly, what stands out in Anijam is the extraordinary union of a variety of personalities - as diverse as Zdenko Gasparovic, Guido Manuli, Frank Terry, Paul Driessen, Frank Nissen or Zlatko Grgic. Each of them brought the proposal to their ground, with a mix of media that included pastel drawing or computer graphics, producing a strong contrast to the cartoon design originally provided by Newland. Anijam, a ten-minute long film, was a production by International Rocketship Ltd., with the financial support of The Canada Council.

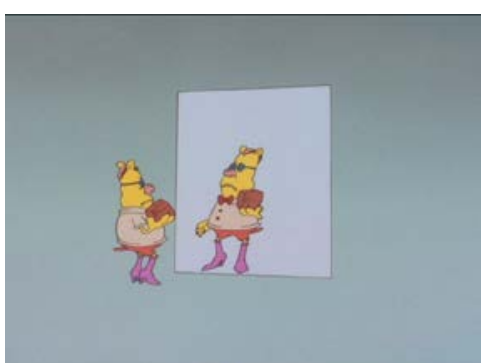

Fig. 1

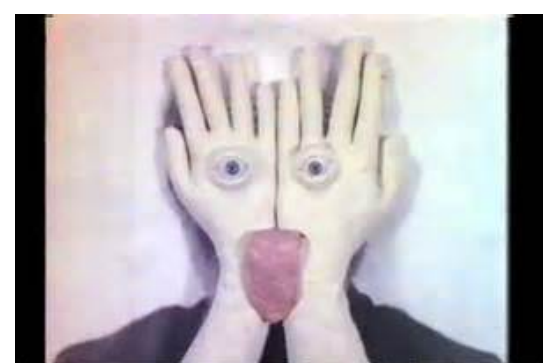

Fig. 2
Fig. 2. Marv Newland's conductor character in Anijam (1984).

Fig. 2. Jan Švankmajer's selfparody in Animated SelfPortraits (1989).

Equally, David Ehrlich's initiative, Animated Self-Portraits (1989), was granted by ASIFA. In this eight-minute long American-Czechoslovak-Estonian-Japanese film, 27 animators creatively portrayed themselves through short scenes; these self-portraits combined symbolism, caricature, a wise use of ellipsis and, of course, large doses of Surrealism. Its many contributors - like Jiří Barta, Borivoj Dovnikovic-Bordo, Kihachiro Kawamoto, Bill Plympton, Jan Švankmajer, or Osamu Tezuka - depicted themselves using the style or graphical technique that best defined them as artists. For instance, Bill Plympton featured a funny deconstruction of his own face, drawn with crayons, while Švankmajer animated photographs and malleable materials, flesh, and prosthetic elements. Each musical piece was also unique, determined by each participant, so the harmonization of the whole fell on the shared subject 
and the prevalence of self-parody. Above all, in the film not only does the self-portrait of the animator stand out as a person but also as a professional, and ultimately, the search for identity in a continuum of metamorphosis.

In 1996, Christine Panushka organized the Absolut Panushka online festival, sponsored by Absolut vodka; thus, 32 animators from all above the world were invited to produce a 15 seconds clip, taking the shape of the bottle of vodka as leit motiv. The show was performed by renowned animators as Vibeke Sorensen, Maureen Selwood, Lejf Marcussen, Priit Pärn or Christine Panushka herself, producing scenes where prevailed humour and experimental techniques - some of these clips, like Absolute Pärn, caused certain controversy for their erotic and satiric mood ${ }^{2}$. The set of contributions collected in the film Absolut Panushka Festival of Films (1997) won several international awards, and they even came to title a website about experimental animation, conducted by the theorist William Moritz.

In more recent years, the most remarkable example of animated 'jams' is perhaps provided by Yellow Sticky Notes / Canadian Anijam (Jeff Chiba Stearns, 2013), a collective film that reproduces the formula of Stearns' personal short Yellow Sticky Notes (2008). The project's history is told by the film itself: in April 2012, Stearns invited 15 independent animators - resident in Canada - to reflect on their daily life, in the form of "things to do" list. The film is divided into a series of vibrant illustrations of real life, though often filtered by absurd humour and irony, all them animated on the same format: the usual yellow sticky notes from our desks. In the film participated mythical Canadian animators as Cordell Barker, Allison Snowden and David Fine, Chris Hinton, or, again, Marv Newland, who also mentored the project. The scenes not only refer to the commonness of the authors - each with its own drawing style -, but also to global events that affect our lives like the planet overpopulation or the presidential elections in the United States - among other events that became international news, like the sinking of Costa Concordia-. The film was sponsored by Bravo! FACT (Foundation to Assist Canadian Talent), and it was completed in a few months.

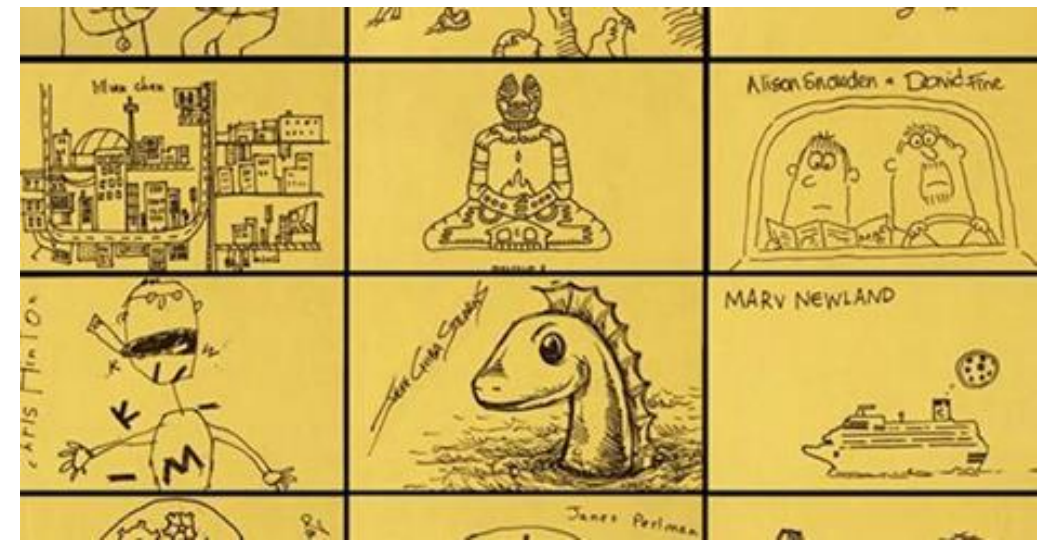

Fig. 3. Diverse contributions to Jeff Chiba Stearns' Yellow Sticky Notes | Canadian Anijam (2013).

In short, animated 'jams' are a lively vehicle for imagination and the search for new languages, as well as a refreshing pretext to make films based on joint efforts and the sum of personalities, to overcome the usual obstacles of planning and financing that often undermine independent production. Animated 'jams' also prove that a few simple conditions stimulate inventiveness more than absolute autonomy, resulting in films unrepeatable by other 
production systems - even those with more material resources. Finally, although the cases observed in this section belong to consecrated animators, the variety of coordination systems to produce animated 'jams' also allow the collaboration of amateur animators - or those to approach to animation for the first time, as will be discussed in the next section.

\section{Part 2_Animated 'jams' as a training experience}

As noted above, collective films are a very widespread method to gather the students' practices at animation schools, especially when the practices are done with the only purpose to gain experience and they do not hold any narrative intention. In this sense, the compilation is a fancy way of presenting these training results, which never had a self-conclusive intention.

However, the realization of collective films often becomes the target of intensive workshops, especially when they gather students from different learning levels. Then, animated 'jams' are a very useful method to mitigate the insecurity of less skilled students towards the new medium, showing that they can achieve conceptual and aesthetically interesting results with effort and determination. The guest lecturers who teach these workshops are usually experimental animators, and they share with students their own way of doing; so, the animated 'jams' derived from these practices may seem quite close to the films by these artists themselves, who serve as models for the students.

This way, in relation to Jeff Chiba Stearns' proposal, it is worth mentioning his workshop Yellow Sticky Notes taught to young students from Lyceum Plastyczne Supras (Supral's Art High School), parallel to the Short Film Festival Żubroffka 2014 (Białystok, Poland). The students were initiated into animation by such an economical and intuitive animation process as flipbooks, using memory notes blocks to draw and to record two animated 'jams'.

Moreover, it must be highlighted the extensive experience that other experimental animator, Japanese Maya Yoneshô ${ }^{3}$, is sharing in schools and art centers around the world. In Yoneshô's visual language, the use of flipbooks plays a primary role, where cheerful abstract watercolours dance synchronized with music. In her personal film Wiener Wuast (Maya Yoneshô, 2006) she combined different media such as her flipbooks and photographic backgrounds, in this case consecutive snapshots of Vienna. Since 2006, she has been devoted to teaching workshops under the generic title Daumenreise Projekt, which has led her to destinations as diverse as Norway, Israel, Italy or Morocco, under the auspices of film festivals or cultural centers. For example, in Bologna she coordinated the animated 'jam' Sottalpòrtig (Under the Arcade, 2012), where the flipbooks animated by young students were superimposed on a photographic tour of the Italian city, achieving some degree of interactivity between the animations and the real scenario. Yoneshô often imparts these workshops also among the smallest ones, giving as result videos like Barnadís. Trossets of Barcelona (2013).

Ultimately, the animated 'jam' Berbaoc (2008) deserves to be underlined: it was produced in Arteleku, San Sebastián (Spain), from the workshop given by Vuk Jevremovic ${ }^{4}$, gaining great notoriety among animation festivals. The film represents an extraordinary evolution of images created with the most diverse materials and processes: drawing with 
charcoal, pixiliation, stop-motion, painting, etc., standing textural values and the materiality of painting. The result is an expressive display inspired by the haunting music of Xabier Erquizia, created from an interview with musician Santiago Irigoien. It was animated by five artists, some of whom had already taken important steps in auteur animation: Joseph Belmonte, Irati Fernández, Gustavo Diaz Sosa, Chuneta Sánchez-Agustino and Izibene Oñederra. All them were free to develop their personal language, leading to visual flow associations between entomology, ossuaries, abstraction, ideograms, birth, copulation, dirt, suffocation, exodus, loneliness, and rebirth. All this, while recalling the heterogeneous and evocative work of Vuk Jevremovic himself; the film widely demonstrates the creative personality of each participant.

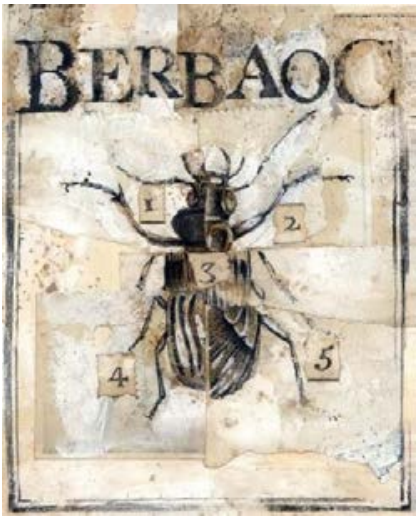

Fig. 4

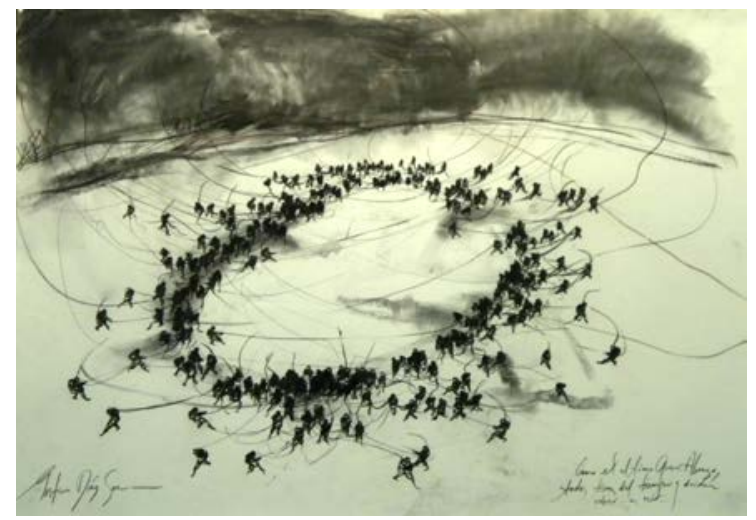

Fig. 5
Fig. 4. Film affiche for Berbaoc (various artists, 2008).

Fig. 5. Gustavo Díaz Sosa's original drawing for Berbaoc.

Now it is time to focus on the films coordinated by Miquel Guillem (Sueca 1953 Valencia 2011, Spain), animation lecturer at the Faculty of Fine Arts, Universitat Politècnica de València. Miquel Guillem began teaching animation in the mid-nineties of the last century, using collective works as a main learning methodology. He coordinated short films, animations for theater productions, and even tributes to important figures from Valencian culture, like $A l$ vent (2010), a music film dedicated to the songwriter Raimón, among many other projects to make visible different social problems through artistic interventions. However, Miquel Guillem was, above all, a provocateur who knew how to get students out of their comfort zone to taste new languages and creative interests.

In this sense, Miquel Guillem was also a noteworthy catalyst for synergies, who above all bet for cooperative work. Miquel Guillem was also able to lead durable projects such as the Master Degree in Animation - UPV - , or the creation of the Researching Group in Animation: Art and Industry UPV, during his brief period as Head of the Department of Design. However, these paragraphs will be restricted to talk about some of the animated 'jams' he promoted, which became another manifestation of his belief that the collective saves the individual.

The short film that he coordinated together with the teacher Sara Álvarez, Flamencos/as (2005), was a surprise at the Spanish animation panorama due to its freshness and spontaneity, excelling in the already disappeared Animadrid Festival. Flamencos/as was originally a proposal to the students of an animation subject centered on experimental techniques - to reinterpret fragments from the art-documentary film by Carlos Saura Sevillanas (1992) through rotoscoping methods. Thus, students re-animated the flouncing skirts of the sevillanas dancing in groups; the click of their heels, the arabesque of their hands, 
or Lola Flores' eternal gaze. Despite its live-action inspiration, Flamencos/as is almost an abstract film where the graphics, the traces, the gesture of the brush seem to fly, but also the clean and sensitive digital tablet lines help to create a genuine and unique work. Miquel Guillem's selection of an acoustic, atonal and repetitive song, gave unity to a short film that did not intend to tell any story, but it just caused excitement to the rhythm of music, of dancing and of the magical confluence of aesthetics.
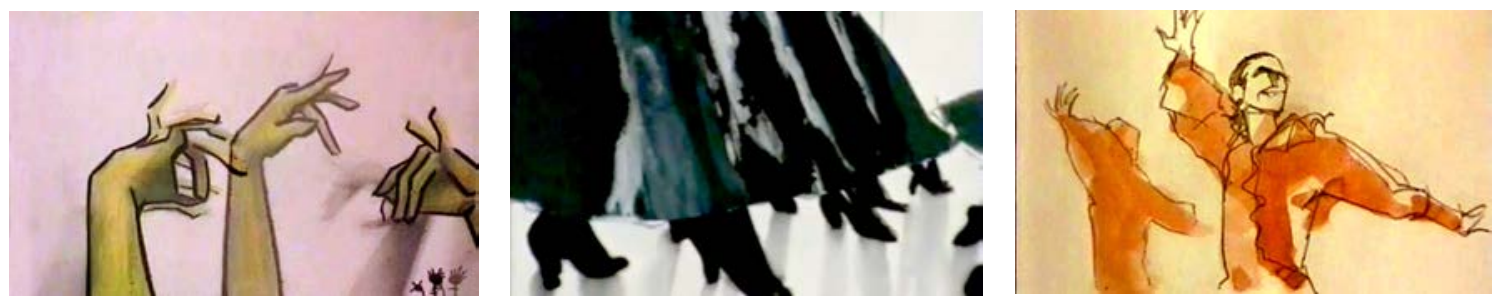

Figs. 6, 7, 8. Flamencos/as (Miguel Guillem, Sara Álvarez [eds.], 2005)

Later, in his last active term at the University, he gathered his students' rotoscope practices under the title Kisses (Miquel Guillem [ed.], 2010), which had as a main subject the most famous kisses from film history - to pay tribute to Giuseppe Tornatore's Cinema Paradiso (1988), and specifically to the emotive scene where the protagonist, Salvatore, watches prohibited footage preserved by his old friend Alfredo, the projectionist. Kisses assembled dreamlike scenes, as Leslie Carol and Gene Kelly kissing while dancing in An American in Paris (Vincente Minnelli, 1951), but also ominous moments, like Michael Corleone's 'Kiss of Death' to his brother Fredo in The Godfather. Part II (Francis Ford Coppola, 1974).

Flamencos/as and Kisses largely surpassed the limits of a mere training practice to become works on their own, thanks to the combination of individual energies that kept their respective personalities intact, but learning to build a common project. This is how Miquel liked to show himself: through incitement, through provocation, offering a starting point.

\section{Part 3_The Cat Dances with its Shadow, a tribute to cinema}

As we have seen, animated 'jams' are characterized by the agility in their execution, being highly dynamic projects with great liberating power. If the participation in animated 'jams' may encourage experienced animators to try new forms of expression - in a short scene unconstrained by commercial commitment - amateur or apprentice animators are opened to new and unexpected ways to acquire skills and knowledge. The responsibility of the coordinator, in turn, is limited to orchestrate the assembly by defining game rules - less than limitations - to which all participants can stick according to their abilities. Later, the coordinator will collect the scenes and give them continuity - according to a preset order, as in Marv Newland's Anijam, or contributing creatively to the result by assuming the editing and synchronization process to a music theme.

Moreover, the use of a common language or particular technique - like the rotoscope - facilitates the ensemble, since the animator may work from pre-existing film footage. In this sense, the coordinator's liability also implies the selection of reference footage that allows all 
animators to argue about the same subject, stating a unique speech from the association between the scenes and their interpretation by each animator.

From September 2011 to March 2012, the Researching Group of Animation: Art and Industry supported a collective project entitled The Cat Dances with its Shadow, where 50 animators participated from Spain and Italy ${ }^{5}$. The idea came from a mere anecdote: the vision of a baby cat playing with its own shadow, cast by a focus of the park. Years before, I had attended a seminar on Spanish cinema where the lecturer, Juan Miguel Company, highlighted the tragic aspects from the old film Carmen (Carmen, la de Triana Florián Rey, 1938), and especially the scene with Carmen dancing on the stage, where only her shadow accompanies her. Since then, bearing in mind the experience of Flamencos/as, I sensed the possibility to create a common project, to talk about film, about mystery, but also about seduction and death.

The opportunity came in 2011, when I was invited for two weeks to teach the subject Animazione Sperimentale at the Master di secondo livello in Animazione digitale: Art and Industry at the Accademia di Belle Arti in Palermo, Italy. The course consisted of various animation practices such as painting under camera, cutouts, and rotoscoping. To interpret rotoscoping creatively, not just as a support to realistic animation, but as an end in itself, seeking an artistic result, the students watched different film samples, such as George Dunning's famous sequence from Yellow Submarine "Lucy in the Sky with Diamonds" (1968), the first films by Georges Schwizgebel - Perspectives (1975) - or pictorial interventions on printed footage on paper, like Gianluigi Toccafondo's films La pista del maiale (1993) or La piccola Russia (2004).

To do this practice, several scenes were selected - six seconds long - from Expressionist cinema where the shadows were playing a prominent role, including: Nosferatu (Nosferatu, eine Symphonie des Grauens, 1922), The Night of the Hunter (Charles Laughton, 1955), Metropolis (Fritz Lang, 1927), M (Fritz Lang, 1931), Bram Stoker's Dracula (Francis Ford Coppola, 1992), or the mentioned Carmen version. Students were free to choose the piece they wanted to animate. Rotoscoping proved to be an excellent support to some students whose animation practice was still at a very early stage, as well as an encouragement to try new aesthetic and conceptual solutions, like Marta Cid's original intervention on Maria's pursuit by the catacombs of Metropolis - converted into an unwitting puppet. As a result of this experience, it was edited an arguably 'beta test' of the project, the provisional film Carmen in the Sky with Diamonds (2011), which brought together the practices by 17 Italian students under the Beatles' well-known music theme.

Back in Spain, the next step was the composition of an original soundtrack, which would encourage more contributors to join the project. As inspiration, the motto by Giorgio de Chirico was proposed: 'There is more mystery in the shadow of a man walking, that in all religions of the world', which heads the film. The original music was written and performed on piano by Armando Bernabeu Lorenzo, award-winning composer and conductor, who created a powerful theme that evoked different moods, like increasing tension, climax, calm and reconciliation, setting the pace of the film properly. Also, I met a group of students and lecturers from the Faculty of Fine Arts in Valencia who wanted to cooperate in the project: 
they watched Carmen in the Sky with Diamonds and understood how they could participate. New titles to the list of proposed films were added such as The Lady from Shanghai (Orson Welles, 1947), The Crow (Alex Proyas, 1994), or other films suggested by the participants, such as Hook (Steven Spielberg, 1991); additionally, it was possible to contribute with time-lapse photography sequences, evoking the poetic of films like Train of Shadows (Tren de sombras, José Luis Guerin, 1997).
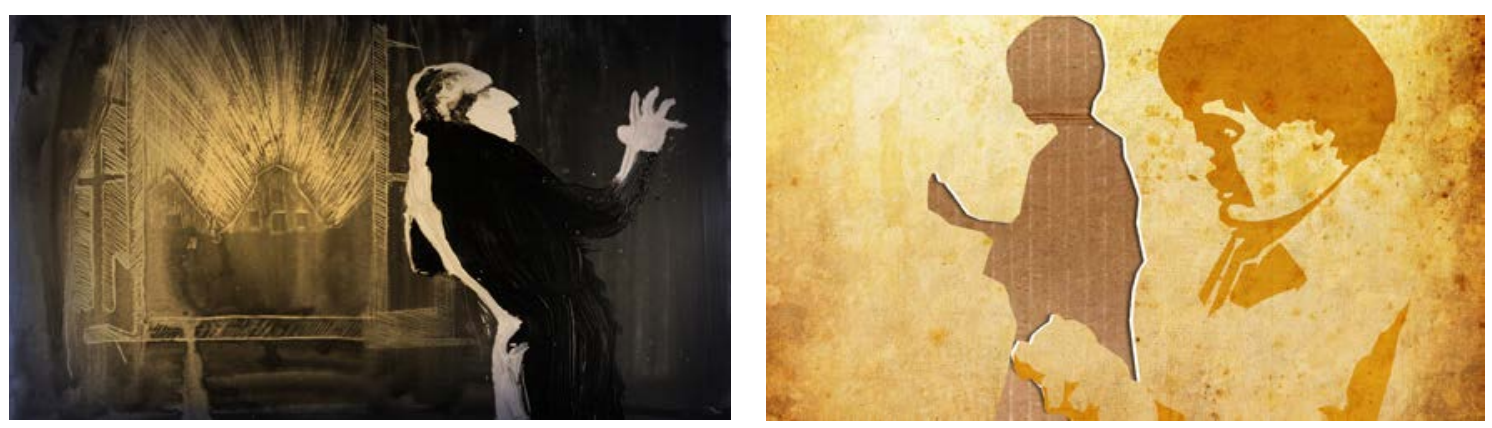

Figs. 9, 10. Laura Llorens' and Eva Figueroa's scenes for The Cat Dances with its Shadow (2012).

In February 2012 animations reception was closed and the editing process began, with the essential condition that no fragment would be discarded - albeit it was necessary, in some cases, to make changes in length and framing. Editing took one month, to adjust conveniently each scene to the music, according to the ideas and associations risen from their combination - for instance, the "crescendo" theme represented pursuits and climbing stairs, while the ending theme fit with characters dancing. The Cat Dances with its Shadow was, therefore, a film where the protagonism of musicality is absolute - although the image has great power by itself, as demonstrated when the film was screened in a special program for the deaf at the Valencian Museum of Fine Arts San Pio V.

The film was selected for its distribution by the official Valencian audiovisual catalogue Curts 20'12" and premiered at IVAC - The Film Archive of Valencia, in June $2012^{6}$. The Cat Dances with its Shadow, a project carried out basically without financing and completed in less than six months, reached more than 30 selections at national and international short film festivals, among them the veteran festival Alcine (Alcalá de Henares), Zinebi (Bilbao), the $16^{\text {th }}$ Malaga Festival Film, but also the Mash Rome Film Festival, or the European Short film Festival at MIT (Massachusetts, USA). The received awards have highlighted the film's originality, including a Mention for Best Aesthetic Proposal in CARTÓN - La Tribu Animation Festival 2012 (Argentina), or the TELSON Award for Best Special Effects, at the Madrid Experimental Film Week 2012.

Ending this section, the 2013 Yearbook of the film magazine Fotogramas described The Cat Dances with its Shadow as a "heartfelt animated tribute to cinema and its myths' However, when we started making it, all of us were unaware that the film would also serve as a posthumous tribute to one of its animators; Miquel Guillem ${ }^{8}$, who not only inspired the concept of the film but consciously contributed to it with his last artistic production - nothing less than a series of self-portraits painted with ink, where he left a fluctuating image of himself, as he was in life: a person always on the move. 


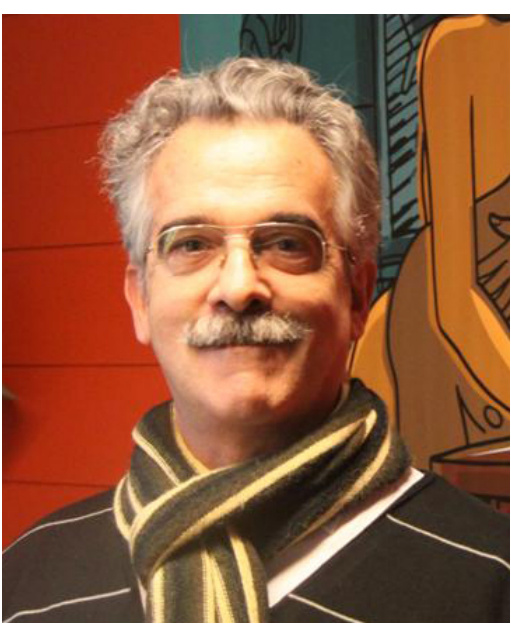

Fig. 31

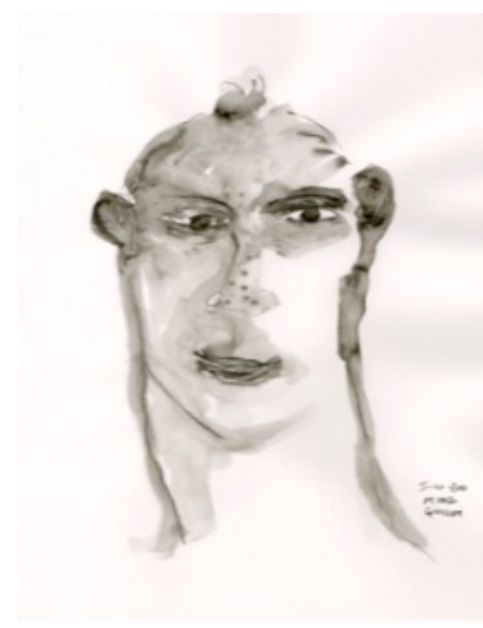

Fig. 12
Fig. 41. Miquel Guillem in 2010.

Fig. 12. Miquel Guillem's last self-portrait appearing in The Cat Dances with its Shadow (September 2011).

\section{Conclusions}

To finish this essay, it is necessary to make some considerations on the feasibility and contributions of animated 'jams' as a means of production. At a time when production funds are drastically cut and many companies have disappeared, collective projects such as Yellow Sticky Notes / Canadian Anijam, Berbaoc, Flamencos/as or The Cat Dances with its Shadow show that we can continue working creatively, conceiving ideas and new procedures to overcome the difficulties that face two scenarios seriously damaged, yet essential to safeguard our culture: University education, and audiovisual industry.

In addition, animated 'jams' have something to teach other industries. The main feature of the 'jams' is that their results are virtually unplayable by other combination of artists, or by a single director establishing a vertical division of labour. On the contrary, each participant owns a fragment, while each scene belongs to the ensemble that gives it meaning. Unlike planned projects, the results of the animated 'jam' are absolutely unpredictable, since it realization responds to the dynamics of 'agile projects', constantly adapting to external and internal conditions rather than to predefined targets, allowing us to identify animated 'jams' as a source of innovation and leveraging opportunities ${ }^{9}$.

I would like to end this paper recovering an idea by Alan Cholodenko, which may be applicable to The Cat Dances with its Shadow. For Cholodenko (2004: 110), the film is an intermediate place, like the crypt of the vampire, the house of the undead ${ }^{10}$; however, when I see in this film the re-animated versions of Robin Williams, Brandon Lee or Patrick Swayze, or the shadow of who Miquel was, I feel profoundly moved and I prefer to regard cinema as the fortunate place where those already gone eternally return.

\section{References}

ANIMA MUNDI, WIEDEMANN, Julius (ed.), 2004, Animation Now!, Colonia: Taschen.

CHOLODENKO, Alan, 2004, 'The Crypt, the Haunted House, of Cinema', in Cultural Studies Review, volume 10, n. 2, September 2004, pp. 99-113. 
FABER, Liz, WALTERS, Hellen, 2004, Animation Unlimited: Innovative Short Films Since 1940, London: Paperback.

FOTOGRAMAS (ed.), 2013, 'Los 99 Cortos del Año', in Anuario 2013, Madrid: Hearst Magazines, pp. 211221.

HOTES, Catherine Munroe, 2008, 'Maya Yonesho', in Nishikata Film Review (http://nishikataeiga.blogspot.com.es/2008/05/maya-yonesho.html [Accessed: December 2014]).

ROBINSON, Chris, 2003, Estonian Animation: Betwen Genius and Utter Illiteracy, London: John Libbey.

TOCCAFONDO, Gianluigi, 2003, Toccafondo. A partire dalla coda, Bolonia: Coconino Press.

YÁÑEZ, Jara, 2012, 'Declaraciones de amor. Catálogo Curts 2012 de la Comunidad Valenciana', in Caimán Cuadernos de Cine, n. 7, July-August 2012, Madrid: Caimán Ediciones, p. 59.

\section{Notes}

\footnotetext{
${ }^{1}$ With the exception of Absolut Panushka Festival of Films, all the short films analyzed in this paper can be watched on the Internet.

2 The bottle animated by Priit Pärn evoked an erect penis under the unequivocal action of a female hand.

3 Maya Yoneshô is an active animator since 1985. Her complete filmography appears listed here: http://homepage3.nifty.com/maya y/Site/works.html (Accessed: December 2014).

${ }^{4}$ To know better this outstanding painter and animator - nominated to the Oscars ${ }^{\circledR}$ in 1999 -, you can visit his website: http://www.vukjevremovic.com/web.asp (Accessed: December 2014).
}

${ }^{5}$ Among its collaborators were the animation instructors Miquel Guillem, Sara Álvarez, Miguel Vidal, Mạ Ángeles López and M. Carmen Poveda; artists like Victoria Cano; and young animators graduated at UPV, who have already achieved recognition at the professional sphere, such as Adriana Navarro, Emilio Martí, Juan Pedro Arroyo, Eva Figueroa, or Rafael Andrés.

6 It is noteworthy that the Curts 20'12" program (http://ivac.gva.es/fomento/fomento-cortometrajevalenciano/curts-cv/el-gato-baila-con-su-sombra [Accessed: December 2014]) only selected six films from a total of 56 produced in Valencia.

7 '[Un] sentido homenaje animado al cine y sus mitos' (p. 216, trad. a.). As well, the film is referenced as follows by Jara Yáñez in Caimán Cuadernos de Cine: 'In a more poetic and open to suggestion tone, The Cat Dances with its Shadow, by María Lorenzo, presents a striking visual play around the shade that also functions as unique tribute to some of the myths of the big screen and, again, as a personal declaration of love (also to movies).' ('En un tono más poético y abierto a la sugestión, El gato baila con su sombra, de María Lorenzo, presenta un llamativo juego visual en torno a la sombra que funciona también como particular homenaje a algunos de los mitos de la gran pantalla y, de nuevo, como personal declaración de amor (también al cine).') Caimán, No. 7, July-August 2012, p. 59. (trad. a).

${ }^{8}$ Miquel Guillem passed away on December the $15^{\text {th }}, 2011$, the same day the Faculty of Fine Arts in Valencia officially awarded him the San Carlos Medal to Artistic Merit.

${ }^{9}$ Agile projects are characterized in the industry for their high flexibility to changes, their lower risks and higher productivity, quality, and motivation of the participating team, besides they facilitate the discovery of innovations (http://www.proyectosagiles.org/introduccion-estimacion-planificacion-agil [Accessed: December 2014]). The Cat Dances with its Shadow was analyzed as a case study of agile project during a working session on Open Innovation at Ericsson Madrid (April 2012). 
10 'Like the spectre, the movie theatre is of the order of the between. To be in it is to be in the haunted house, the crypt, of cinema.' Cholodenko, 2004: 110. 